\title{
Hubungan Promosi Kesehatan Lingkungan dan Peran Bidan terhadap Perilaku Penggunaan Alat Kontrasepsi Dalam Rahim (AKDR)
}

\author{
Wirdia Salsabila Audina', Aida Diana Astarie ${ }^{2}$ \\ ${ }^{1,2}$ Program Studi Kebidanan Program Sarjana Terapan Sekolah Tinggi Ilmu Kesehatan Indonesia Maju \\ Jln.Harapan Nomor 50, Lenteng Agung-Jakarta Selatan 12610, Indonesia \\ Telp: (021) 78894045, Email: Wirdiasalsabilaaudina@gmail.com'; Aidadiana@gmail.com²
}

\begin{abstract}
Abstrak
Perilaku penggunaan Alat Kontrasepsi Dalam Rahim (AKDR) adalah suatu sikap yang dilakukan responden pengguna KB berdasarkan jenis alat kontrasepsi IUD maupun alat kontrasepsi yang lain. Tujuan penelitian ini adalah untuk mengetahui bagaimana hubungan promosi kesehatan, lingkungan dan peran bidan terhadap perilaku penggunaan Alat Kontrasepsi Dalam Rahim (AKDR) di Puskesmas Perumnas I Pontianak Kalimantan Barat Tahun 2017. Metodologi penelitian ini adalah analitik kuantitatif dengan menggunakan desain penelitian cross sectional. Populasi dalam penelitian ini adalah seluruh wanita yang menggunakan AKDR. Sampel penelitian ini menggunakan total populasi yaitu wanita yang menggunakan AKDR sebanyak 30 orang. Instrumen yang digunakan adalah kuesioner. Pengolahan data dilakukan dengan menggunakan chi square, dengan analisis data univariat dan bivariat. Hasil penelitian promosi kesehatan dengan perilaku penggunaan AKDR $P$-Value 0,004 , yang artinya ada hubungan promosi kesehatan dengan perilaku penggunaan AKDR dengan OR 15,556 (2,586-93,571). Hasil penelitian lingkungan terhadap perilaku penggunaan AKDR P-Value 0,001 yang artinya ada hubungan lingkungan dengan perilaku penggunaan AKDR dengan OR 25,000 (3,52217,477). Kesimpulannya ada hubungan promosi kesehatan, lingkungan dan peran bidan terhadap perilaku penggunaan AKDR di Puskesmas Perumnas I Pontianak. Diharapkan untuk memperbaiki perilaku penggunaan AKDR maka promosi kesehatan harus selalu dilakukan dan lebih ditingkatkan sehingga pengguna AKDR mempunyai perilaku yang baik.
\end{abstract}

Kata Kunci : Promosi Kesehatan, Lingkungan, Peran Bidan dan Perilaku Penggunaan AKDR

\begin{abstract}
Gold period can be realized if the child at this time get the appropriate food to grow and develop to be optimal. Behavior of the use of Intrauterine Device (IUD) is an attitude that respondents use KB users based on the type of IUD contraceptive devices and other contraceptives. The purpose of this study is to find out how the relationship of health promotion, environment and role of midwife to behavior of Intrauterine Contraception (IUD) in Perumnas I Pontianak West Borneo 2017. The methodology of this research is quantitative analysis using cross sectional research design. The population in this study were all women who used IUD. The sample of this study using the total population of women who use IUD as many as 30 people. The instrument used is a questionnaire. Data processing was done by using chi square, with univariate and bivariate data analysis. The result of health promotion research using PDR Value I 0,004, which means there is a health promotion relationship with behavior of IUD use with OR 15,556 (2,586-93,571). The results of environmental research on the use of P-Value IUD 0.001 which means there is an environmental relationship with the use of IUD with 25,000 (3,522-17,477). In conclusion there is a relationship of health promotion, environment and role of midwife to behavior of IUD usage at Puskesmas Perumnas I Pontianak. It is expected that to improve the behavior of IUD use, health promotion should always be done and enhanced so that the IUD users have good behavior.
\end{abstract}

Keywords $\quad$ : Cervical Cancer, Human Papilloma Virus Vaccine, Learning Method 


\section{Pendahuluan}

Keluarga berencana merupakan tindakan yang bermanfaat bagi individu untuk menghindari kelahiran yang tidak diinginkan, mengatur jarak kehamilan dan menetapkan jumlah anggota keluarga yang diinginkan. ${ }^{1}$ Menurut World Health Organization (WHO) tahun 2014 pemakaian alat kontrasepsi telah menanjak di berbagai belahan dunia, utamanya di bagian Asia dan Amerika Latin dan sedikit digunakan di Sub Sahara Afrika. Secara garis besar, penggunaan alat kontrasepsi modern telah meningkat dari 54\% pada tahun 1990 menjadi $57,4 \%$ pada tahun 2014. Pada konferensi internasional tentang kependudukan dan pembangunan (ICPD Kairo, 1994) disepakati perubahan paradigma dari pendekatan pengendalian populasi dan penurunan fertilitas menjadi lebih ke arah pendekatan kesehatan reproduksi dan kesetaraan gender. $^{2}$

Tak hanya dibelahan dunia, di Indonesia pengembangan total masyarakat juga meningkat. Menurut World Health Organization (WHO) Indonesia menempatkan dirinya sebagai negara berkembang terbesar nomor 4 di dunia yang mempunyai jumlah penduduk sebesar 238.452.952 jiwa. $^{3}$ Hasil semua sensus menurut publikasi Badan Pusat Statistik (BPS) pada bulan Agustus tahun 2010 antara lain jumlah penduduk Indonesia adalah 273.556.263 jiwa, tedapat 119.507.600 lakilaki dan 118.048 .783 perempuan dengan peningkatan sebesar $1,49 \%$ pertahun.

Cakupan peserta KB baru dan KB aktif di Indonesia pada Tahun 2014 dengan jumlah Pasangan Usia Subur (PUS) sebanyak 47.019.002 sedangkan peserta KB baru sebesar 7.761.961 (16,15\%) khususnya AKDR (Alat Kontrasepsi Dalam Rahim) sebanyak 555.241 $(7,15 \%)$, sedangkan peserta KB baru sebesar 7.761.961 (16,15\%) khususnya AKDR (Alat Kontrasepsi Dalam Rahim) sebanyak 555.241 $(7,15 \%)$, sedangkan peserta KB aktif sebanyak 35.202.908 khususnya AKDR sebanyak $3.896 .081(11,07 \%)^{4}$.

Beberapa penelitian menyebutkan bahwa kurangnya pemakaian alat kontrasepsi Alat Kontrasepsi Dalam Rahim (AKDR) karena ketidaktahuan pengguna tentang keunggulan dari metode kontrasepsi IUD yang informasinya tidak disampaikan oleh petugas kesehatan.
Penelitian Katz menunjukkan bahwa rendahnya pemakaian metode kontrasepsi jangka panjang terutama IUD di El Salvador karena tiga hal adanya rumor dan mitos tentang metode kontrasepsi tersebut yang kurang baik, tidak cukupnya perhatian terhadap metode tersebut selama pelayanan keluarga berencana dan tidak cukupnya jumlah pemberi pelayanan keluarga. Tingkat pemakaian metode KB jangka panjang, yaitu IUD, implan, metode operasi atau vasektomi, dan metode operasi wanita atau tubektomi hanya sebesar $10,6 \% .^{5}$

Berdasarkan fenomena tersebut dapat diartikan bahwa cakupan berKB di Indonesia masih sangat di dominasi oleh kaum wanita tetapi hanya KB suntik dan pil. Rendahnya partisipasi dalam KB IUD dikarenakan masih banyak wanita yang mengalami kekhawatiran terhadap penggunaan alat kontrasepsi ini, takut pada saat proses melakukan Alat Kontrasepsi Dalam Rahim (AKDR) ini dan saat proses melakukan Alat Kontrasepsi Dalam Rahim (AKDR) ini dan sebagainya. dilihat dari akses informasi, materi informasi wanita masih sangat terbatas dalam mendapatkan informasi mengenai KB Alat Kontrasepsi Dalam rahim (AKDR) ini. Keterbatasan juga dilihat dari sisi pelayanan dimana sarana/ tempat pelayanan yang dapat mengakomodasikan kebutuhan KB dan pemasangan Alat Kontrasepsi Dalam Rahim (AKDR) karena hanya tenaga kesehatan tertentu yang dapat melayani pemasangan alat kontrasepsi ini.

Provinsi Kalimantan Barat berada diatas rata-rata nasional dengan penggunaan alat kontrasepsi modern sebanyak $65,42 \%$ dari rata-rata di Indonesia yang menggunakan alat kontrasepsi sebesar 58,99\%. Pemakaian alkon di Provinsi Kalimantan Barat khususnya AKDR sebesar $(3,06 \%)$ dari $65,42 \%$ yang menggunakan alkon modern.

Memasuki era otonomi daerah yang ingin mewujudkan organisasi perangkat daerah yang ideal, maka Peraturan Pemerintah Nomor 8 Tahun 2003 tentang pedoman organisasi perangkat daerah secara konkret menggunakan pendekatan wajib sebagaimana diatur dalam Undang - Undang Nomor 22 Tahun 1999

tentang pemerintah daerah. Pendekatan ini digunakan dalam rangka mengukur urgensi pembentukan organisasi perangkat daerah dapat di lihat di penjelasan umum Peraturan 
Pemerintah Nomor 8 Tahun 2003 yang diarahkan semaksimal mungkin mendekati kebutuhan nyata secara rasional objektif. Otonomi daerah terjadi restruksi organisasi di hampir semua instansi pemerintah di daerah termasuk KB. Semula instansi yang menangani KB di daerah yaitu BKKBN Kabupaten/Provinsi dan masih dibawah kendali BKKBN Pusat, sejak otonomi daerah instansi yang menangani KB diserahkan sepenuhnya kepada pemerintah daerah.

Ada yang digabungkan di dinas lain ada yang dipertahankan. Keluarga Berencana adalah usaha untuk mengontrol jumlah dan jarak kelahiran anak, untuk menghindari kehamilan yang bersifat sementara dengan menggunakan kontrasepsi sedangkan untuk menghindari kehamilan yang sifatnya menetap yang bisa dilakukan dengan cara strelisasi.

Berdasarkan penelitian dari Yeni Elviani menyatakan bahwa tidak ada hubungan yang bermakna antara usia terhadap penggunaan kontrasepsi. ${ }^{6}$ Sedangkan berdasarkan hasil penelitian dari Siti Widiyawati, Mappety Nyorong, dan Sudirman Nasir Tahun 2012 menyatakan bahwa hasil tiap variabel menunjukkan bahwa ada hubungan yang bermakna pemakaian AKDR dengan pendidikan, dukungan suami dan pengetahuan, ${ }^{7}$

Lingkungan adalah kesatuan ruang dengan semua benda, daya, keadaan dan makhluk hidup termasuk manusia dan perilakunya yang memengaruhi kelangsungan peri kehidupan dan kesejahteraan manusia serta makhluk hidup lain (Pasal 1 ayat 1 ). ${ }^{8}$ Dalam hal ini lingkungan dapat menjadi salah satu faktor penyebab rendahnya penggunaan alat kontrasepsi ini, karena jika lingkungan mendukung penggunaan alat kontrasepsi ini maka penggunaan alat kontrasepsi ini dalam berKB di Indonesia akan meningkat.

Menurut penelitian dari Dyah Retna Puspita bahwa pengaruh langsung dan nyata dari kompetensi dan lingkungan dengan koefisien sebesar 0,30 dan 0,50 serta pengaruh langsung dan tidak nyata dari motivasi kerja dengan koefisien sebesar 0,10. Selain promosi

kesehatan dan lingkungan, peran tenaga kesehatan juga memengaruhi penggunaan AKDR. ${ }^{9}$
Peran adalah tingkah laku yang diinginkan sesuai dengan tugas yang diberikan. Peran didasarkan pada preskripsi (ketentuan) dan maksud peran itu dapat memenuhi harapan seusai dengan tingkah laku dan tuigas yang diberikan. ${ }^{10}$

Menurut hasil penelitian yang dilakukan oleh Nur Asri bahwa terdapat hubungan antara peran petugas kesehatan dengan perilaku seksual pada ibu pasca nifas dan terdapat hubungan antara media informasi dengan perilaku seksual pada ibu pasca nifas, ${ }^{11}$

Alat Kontrasepsi Dalam Rahim (AKDR) adalah alat yang terbuat dari plastik serta mempunyai dan mengandung hormon yang dimasukkan ke dalam rahim melalui vagina. ${ }^{12}$

Menurut penelitian dari Siti Widiyawati dan Sudirman Natsir yang berjudul "FaktorFaktor yang Berhubungan Dengan Pemakaian AKDR (Alat Kontrasepsi Dalam Rahim) di Wilayah Kerja Puskesmas Batuah Kutai Kartanegara menyatakan bahwa menunjukkan bahwa ada hubungan antara penggunaan AKDR dengan pendidikan, dukungan suami dan pengetahuan.

Berdasarkan studi pendahuluan yang dilakukan di dapatkan pengguna AKDR di Puskesmas Perum I Pontianak pada tahun 2016 ada sebanyak dari pengguna Alat Kontrasepsi. Oleh karena itu peneliti tertarik untuk melakukan penelitian berjudul "Hubungan Promosi Kesehatan, Lingkungan dan Peran Bidan terhadap Perilaku Penggunaan Alat Kontrasepsi Dalam Rahim (AKDR) di Puskesmas Perum I Pontianak Tahun 2017”.

Tujuan penelitian ini adalah untuk mengetahui bagaimanakah hubungan promosi kesehatan, lingkungan dan peran bidan terhadap perilaku penggunaan Alat Kontrasepsi Dalam Rahim (AKDR) di Puskesmas Perumnas I Pontianak Kalimantan Barat Tahun 2017.

\section{Metode}

Penelitian ini adalah penelitian analisis deskriptif dengan menggunakan metode penelitian kuantitatif dengan desain penelitian

cross sectional. Cross sectional adalah pendekatan yang dilakukan dalam satu waktu saja dan tidak diikuti dalam waktu tertentu. ${ }^{14}$ 
Populasi adalah objek atau subyek yang ditetapkan oleh peneliti karakteristiknya untuk diteliti. Populasi dalam penelitian ini berdasarkan data yang tercatat di puskesmas Perum I didapatkan ibu yang menggunakan Alat Kontrasepsi Dalam Rahim (AKDR) sebanyak 30orang. ${ }^{15}$

Teknik pengambilan sampel dalam penelitian ini menggunakan teknik total sampling yaitu teknik pengambilan sampel dimana jumlah sama dengan populasi.

Kriteria inklusi yang dimaksud dalam penelitian ini adalah wanita yang menggunakan Alat Kontrasepsi Dalam Rahim (AKDR) Di wilayah Kerja Puskesmas Perum I Kota Pontianak Tahun 2017 dan yang bersedia menjadi responden pada saat penelitian dilakukan

Kriteria non inklusi dalam penelitian ini adalah wanita yang tidak menggunakan Alat Kontrasepsi Dalam Rahim (AKDR) di wilayah kerja puskesmas Perum I Kota Pontianak Tahun 2017.

Peneliti melakukan uji validitas dan reliabilitas dengan menggunakan rumus pearson product momment. Instrumen berupa kuisioner berjumlah 50 soal. Validitas merupakan pengukuran yang dilakukan untuk melihat valid atau tidaknya instrumen penelitian yang digunakan. Uji valid ini untuk melihat seberapa besar instumen dalam menjalankan fungsinya. Instrumen dikatakan valid apabila dapat digunakan untuk melakukan pengukuran yang akan di ukur. ${ }^{16}$

Pengumplan data yang digunakan adalah mengunakan data primer, data yang diperoleh dari pengambilan kuesioner kepada pengguna AKDR. Peneliti membuat surat permohonan izin melakukan penelitian dari kepala puskesmas perumnas I dan setelah mendapat izin peneliti melaksanakan pengumpulan data di puskesmas perumnas I Pontianak.

Data diolah dengan menggunakan komputerisasi. Data kemudian di input atau di entri. Coding merupakan pemberian kode numerik atau angka terhadap data yang terdiri atas beberapa kategori. Checking melakukan pemeriksaan pada data yang akan dilakukan pengolahan, kegiatan ini dilakukan agar data yang diperoleh sesuai dengan yang ada.
Cleaning merupakan kegiatan pengecekan kembali data yang sudah di entri agar tidak ada kesalahan. Kesalahan tersebut dimungkinkan terjadi pada saat kita mengentri ke komputer. Dalam proses cleaning ini saya meminta bantuan kepada teman untuk mengoreksi kembali apa bila terdapat kesalahan data. Data bersih merupakan data yang sudah melewati coding, cheking, dan clening dan siap untuk dilakukan pengolahan.

Analisa data dalam penelitian ini menggunakan bantuan komputerisasi SPSS 16. Dimana hasilnya meliputi analisa univariat yaitu mendeskripsikan setiap variabel dan analisa bivariat yaitu uji t-test uji $T$ independent untuk membandingkan dua kelompok yang mempunyai subjek yang berbeda.

Analisis univariat dilakukan terhadap tiap variabel dari hasil penelitian. Pada umumnya dalam analisa ini hanya menghasilkan distribusi frekuensi dan presentasi dari variabel dependen atau variabel terikat (perilaku penggunaan AKDR) dengan variabel independen atau variabel bebas yaitu (promosi kesehatan, lingkungan dan peran bidan).

Pengujian statistik menentukan apakah hipotesa ditolak atau gagal ditolak dengan menggunakan program komputerisasi. Kriteria pengujian adalah jika $\mathrm{p}$-value $<0,05$ maka Ho ditolak, jika p-value >0,05 maka Ho gagal ditolak.

Penyajian data yang dilakukan dalam penelitian ini adalah penyajian data dalam bentuk tabel untuk memberikan keterangan berbentuk angka. Penyajian data dalam bentuk teks dan narasi dilakukan untuk memberikan keterangan secara tulisan. Interpretasi disampaikan secara narasi sehingga memudahkan pemahaman terhadap hasil penelitian, interpretasi digunakan untuk meliahat perbedaan.

\section{Hasil}

\section{Analisis Univariat}

Analisis univariat dilakukan terhadap tiap variabel dari hasil penelitian. Pada umumnya dalam analisa ini hanya menghasilkan distribusi variabel yang diamati. 
Tabel 1. Distribusi frekuensi promosi kesehatan, lingkungan dan peran bidan terhadap perilaku penggunaan AKDR

\begin{tabular}{lcc}
\hline \multicolumn{1}{c}{ Variabel } & $\begin{array}{c}\text { Frekuensi } \\
(\mathbf{f})\end{array}$ & $\begin{array}{c}\text { Presentase } \\
(\%)\end{array}$ \\
\hline Perilaku Penggunaan AKDR & \\
$\quad$ Baik & 17 & 57 \\
$\quad$ Kurang Baik & 13 & 43 \\
$\begin{array}{l}\text { Promosi Kesehatan } \\
\quad \text { Baik }\end{array}$ & 17 & 57 \\
$\quad$ Kurang Baik & 13 & 43 \\
$\begin{array}{l}\text { Lingkungan } \\
\quad \text { Mendukung }\end{array}$ & 18 & 60 \\
$\quad$ Kurang & & \\
$\quad$ Mendukung & 12 & 40 \\
Peran Bidan & & \\
$\quad \begin{array}{l}\text { Mendukung } \\
\text { Kurang }\end{array}$ & 16 & 53 \\
$\quad$ Mendukung & 14 & 47 \\
\hline
\end{tabular}

Ini dilakukan untuk mengetahui frekuensi dan gambaran dari tiap-tiap variabel baik variabel independen maupun variabel dependen (perilaku penggunaan AKDR). Berdasarkan hasil analisis pada tabel 1 distribusi perilaku penggunaan AKDR menunjukkan bahwa dari total 30 responden yang memiliki perilaku penggunaan AKDR baik sebanyak 17 (57\%) dan sebanyak $13(43 \%)$ memounyai perilaku penggunaan AKDR kurang baik.

Distribusi frekuensi promosi kesehatan menunjukkan bahwa dari total 30 responden yang mendapatkan promosi kesehatan yang baik sebanyak 17 orang $(57 \%)$ dan mendapatkan promosi kesehatan yang kurang baik sebanyak 13 orang (43\%).

Distribusi frekuensi lingkungan menunjukkan bahwa dari total 30 responden yang merasakan lingkungan yang mendukung sebanyak 18 orang $(60 \%)$ dan yang merasakan lingkungan yang kurang mendukung sebanyak 12 orang (40\%).

Distribusi frekuensi peran bidan menunjukkan bahwa dari total 30 responden mengatakan peran bidan sangat mendukung sebesar 16 orang $(53 \%)$ dan yang mengatakan peran bidan yang kurang mendukung sebesar 14 orang (47\%).

\section{Analisis Bivariat}

Analisis bivariat dilakukan untuk mengetahui apakah ada hubungan variabel independen dengan variabel dependen dengan tingkat kemaknaan alpha sebesar 0,05.

Berdasarkan hasil analisis pada tabel 2 dibawah hasil uji statistik chi square dengan batas kemaknaan $\alpha=0,05$ didapatkan hasil $p$ value $0,004<0,05$. Hal ini menunjukkan ada hubungan promosi kesehatan dengan perilaku penggunaan AKDR.

\section{Hasil analisis hubungan lingkungan dengan perilaku penggunaan AKDR menunjukkan 18 responden yang merasakan Ini dilakukan untuk mengetahui frekuensi dan gambaran dari tiap-tiap variabel baik variabel independen maupun variabel dependen (perilaku penggunaan AKDR). Lingkungan yang mendukung dalam kategori baik sebesar 15 responden $(60 \%)$ dan 2 responden $(6,7 \%)$ yang kurang mendukung, sedangkan dari 12 responden yang lingkungan yang kurang mendukung dalam kategori baik sebanyak 2 responden $(6,7 \%)$ dan $10(33,3 \%)$ yang kurang baik.}

Hasil uji statistik chi square dengan batas kemaknaan $=0,05$ didapatkan hasil $\mathrm{p}$ value $0,001<0,05$. Hal ini menunjukkan ada hubungan lingkungan dengan perilaku penggunaan AKDR di Puskesmas Perumnas I Pontianak Kalimantan Barat Tahun 2017. Dengan nilai OR 25,000 yang berarti lingkungan yang mendukung berpeluang 25 kali akan berperilaku baik dibanding dengan lingkungan yang kurang mendukung.

Hasil analisis hubungan antara peran bidan dengan perilaku penggunaan AKDR menunjukkan sebanyak 13 orang $(43,3 \%)$ peran bidan yang mendukung dan berperilaku baik sedangkan 3 orang (10\%) mengatakan peran bidan yang mendukung tetapi perilaku penggunaan AKDR baik sebanyak 4 orang $(13,3 \%)$ dan responden yang mengatakan peran bidan yang kurang mendukung namun berperilaku kurang baik sebanyak 10 orang $(33,3 \%)$.

Hasil uji statistik nilai $\mathrm{P}=0,001$ dalam hal ini nilai $\alpha<0,05$ yaitu Ho ditolak dan $\mathrm{Ha}$ diterima maka dapat disimpulkan bahwa 
hubungan peran bidan terhadap perilaku penggunaan AKDR. Dari hasil nilai OR 95\% CI adalah $10,833(1,961-59,833)$ yang artinya peran bidan yang mendukung berpeluang $10,8 \mathrm{x}$ mendapatkan perilaku penggunaan AKDR yang baik dibandingkan dengan peran bidan yang kurang mendukung.
Berdasarkan hasil penelitian yang dilakukan oleh Fergi Indah Diniarti (2017) tentang pengaruh penyuluhan IUD dengan minat menggunakan IUD pada wanita usia 3544 tahun kelurahan Tegal Panggung Yogyakarta didapatkan hasil ada pengaruh dalam penyuluhan IUD dengan minat

Tabel 2. Hubungan Promosi Kesehatan Lingkungan Dan Peran Bidan Terhadap Perilaku Penggunaan Alat Kontrasepsi Dalam Rahim (AKDR)

\begin{tabular}{|c|c|c|c|c|c|c|c|c|}
\hline \multirow{3}{*}{ Variabel Penelitian } & \multicolumn{4}{|c|}{ Perilaku Penggunaan AKDR } & & & \multirow{3}{*}{ P value } & \multirow{3}{*}{ OR } \\
\hline & \multicolumn{2}{|c|}{ Baik } & \multicolumn{2}{|c|}{ Kurang Baik } & \multicolumn{2}{|c|}{ Total } & & \\
\hline & $\mathbf{f}$ & $\%$ & $\mathbf{F}$ & $\%$ & $\mathbf{N}$ & $\%$ & & \\
\hline \multicolumn{9}{|l|}{$\overline{\text { Promosi Kesehatan }}$} \\
\hline Baik & 14 & 46,3 & 3 & 10 & 17 & 56,6 & \multirow[b]{2}{*}{0,004} & 15,556 \\
\hline Kurang Baik & 3 & 10 & 10 & 32 & 13 & 43,4 & & $\begin{array}{l}(2,856- \\
93,571)\end{array}$ \\
\hline \multicolumn{9}{|l|}{ Lingkungan } \\
\hline Mendukung & 15 & 50 & 3 & 10 & 18 & 60 & \multirow[b]{2}{*}{0,001} & 25,000 \\
\hline Kurang Mendukung & 2 & 6,7 & 10 & 33,3 & 12 & 40 & & $\begin{array}{r}(3,522- \\
177,477)\end{array}$ \\
\hline \multicolumn{9}{|l|}{ Peran Tenaga Kesehatan } \\
\hline Mendukung & 13 & 43,3 & 3 & 10 & 16 & 53,4 & \multirow[b]{2}{*}{0,001} & 10,833 \\
\hline Kurang Mendukung & 4 & 13,3 & 10 & 13,3 & 14 & 46,6 & & $\begin{array}{l}(1,961- \\
59,834)\end{array}$ \\
\hline
\end{tabular}

\section{Pembahasan}

\section{Hubungan Promosi Kesehatan terhadap Perilaku Penggunaan AKDR}

Hasil uji statistik menunjukkan ada hubungan promosi kesehatan terhadap perilaku penggunaan AKDR Hasil uji statistik 30 responden yang mendapatkan promosi kesehatan yang baik sebanyak 17 orang (57\%) dan yang mendapatkan promosi kesehatan yang kurang baik sebanyak 13 orang (43\%). Dari hasil uji statistik didaptkan nilai hasil $\mathrm{p}$ value $0,004<0,05$. Hal ini menunjukkan ada hubungan promosi kesehatan dengan perilaku penggunaan AKDR. Dengan nilai OR 15,556 $(2,856-93,571)$ artinya promosi kesehatan yang baik berpeluang 15,5 kali berpeluang baik dibandingkan dengan promosi kesehatan yang kurang baik.

Program promosi kesehatan dan pencegahan penyakit fokus pada menjaga orang sehat. Promosi kesehatan melibatkan dan memberdayakan individu dan masyarakat untuk terlibat dalam perilaku sehat, dan membuat perubahan yang mengurangi risiko pengembangan penyakit kronis dan morbiditas lainnya. ${ }^{21}$ menggunakan IUD pada wanita usia 35-44 tahun di Kelurahan Tegal Panggung Yogyakarta. Berdasarkan hasil uji analisa didapatkan hasil $P$ value $>0,05$ yaitu sebesar $0.005 .^{22}$

Berdasarkan pendapat peneliti dari hasil penelitian yang dilakukan didapatkan hasil bahwa perilaku penggunaan AKDR dapat dipengaruhi oleh promosi kesehatan. Hal ini kurang baiknya promosi kesehatan yang diberikan oleh petugas kesehatan. Jika promosi kesehatan yang dilakukan oleh petugas kesehatan baik maka perilaku penggunaan AKDR juga akan membaik.

\section{Hubungan Lingkungan terhadap Perilaku Penggunaan AKDR}

Hasil uji statistik menunjukkan ada hubungan lingkungan terhadap perilaku penggunaan AKDR Hasil analisis hubungan lingkungan dengan perilaku penggunaan AKDR menunjukkan 18 responden yang merasakan lingkungan yang mendukung dalam kategori baik sebesar 15 responden (60\%) dan 2 responden $(6,7 \%)$ yang kurang mendukung, sedangkan dari 12 responden yang lingkungan yang kurang mendukung 
dalam kategori baik sebanyak 2 responden $(6,7 \%)$ dan $10(33,3 \%)$ yang kurang baik.

Hasil uji statistik chi square dengan batas kemaknaan $=0,05$ didapatkan hasil $\mathrm{p}$ value $0,001<0,05$. Hal ini menunjukkan ada hubungan lingkungan dengan perilaku penggunaan AKDR di Puskesmas Perumnas I Pontianak Kalimantan Barat Tahun 2017. Dengan nilai OR 25,000 yang berarti lingkungan yang mendukung berpeluang 25 kali akan berperilaku baik dibanding dengan lingkungan yang kurang mendukung.

Lingkungan menjadi salah satu faktor yang dapat memengaruhi perilaku penggunaan AKDR. Lingkungan dapat membantu agar dapat mencapai suatu keberhasilan dalam tujuan. Tujuan dari lingkungan adalah dapat memberikan pendidikan kesehatan yang baik kepada pengguna AKDR. ${ }^{23}$

Berdasarkan hasil penelitian yang dilakukan oleh Lutfia Khoirunissa tentang hubungan Lingkungan (Dukungan Suami) dengan pemilihan penggunaan kontrasepsi IUD didapatkan hasil bahwa dari 35 responden didapatkan 23 responden $(65,7 \%)$ mendapatkan lingkungan yang mendukung yang tinggi dan 12 responden $(34,3 \%)$ mendapatkan lingkungan yang sedang sehingga didapatkan ada hubungan antara dukungan suami dengan pemilihan penggunaan kontrasepsi IUD pada akseptor kontrasepsi IUD di Puskesmas TegalRejo Tahun 2014 hasil uji chi-square diperoleh $p$ value $0,01(\mathrm{p}<0,05){ }^{24}$

Menurut pendapat peneliti dari hasil penelitian yang telah dilakukan didapatkan bahwa lingkungan (dukungan suami) dapat memengaruhi perilaku pengguna AKDR. Apabila lingkungan mendukung maka perilaku pengguna AKDR juga akan baik tetapi jika lingkungan yang kurang mendukung akan menghasilkan perilaku pengguna AKDR yang kurang baik. Hal ini dikarenakan kurangnya dukungan dari lingkungan terutama suami dalam hal penggunaan AKDR ini mengakibatkan perilaku pengguna AKDR yang kurang baik sehingga terjadilah peningkatan kelahiran. Jika dukungan lingkungan semakin baik maka tidak akan terjadi peningkatan kelahiran dan secara langsung terjadinya peningkatan penggunaan AKDR.

\section{Hubungan Peran Bidan Terhadap Perilaku Penggunaan AKDR}

Hasil uji statistik menunjukkan ada hubungan antara peran bidan dengan perilaku penggunaan AKDR menunjukkan sebanyak 13 orang $(43,3 \%)$ peran bidan yang mendukung dan berperilaku baik sedangkan 3 orang (10\%) mengatakan peran bidan yang mendukung tetapi perilaku penggunaan AKDR baik sebanyak 4 orang $(13,3 \%)$ dan responden yang mengatakan peran bidan yang kurang mendukung namun berperilaku kurang baik sebanyak 10 orang $(33,3 \%)$.

Hasil uji statistik nilai $\mathrm{P}=0,001$ dalam hal ini nilai $\alpha<0,05$ yaitu Ho ditolak dan $\mathrm{Ha}$ diterima maka, dapat disimpulkan bahwa da hubungan peran bidan terhadap perilaku penggunaan AKDR. Dari hasil nilai OR 95\% CI adalah 10,833 $(1,961-59,833)$ yang artinya peran bidan yang mendukung berpeluang $10,8 \mathrm{x}$ mendapatkan perilaku penggunaan AKDR yang baik dibandingkan dengan peran bidan yang kurang mendukung.

Peran bidan adalah tingkah laku yang diharapkan oleh masyarakat kepada bidan yang sesuai dengan standar profesi bidan. Bidan merupakan tenaga kesehatan yang memiliki posisi yang strategis dalam meningkatkan kesejahteraan ibu, bayi, dan balita.Salah satu peran bidan adalah konseling.Bidan adalah ujung tombak pembangunan keluarga sejahtera dari sudut kesehatan dan pemberdayaan lainnya.Karena itu, sebagai ujung tombak dalam bidang kesehatan, bidan dituntut untuk berperan memberi pertolongan dini atau memberi petunjuk dalam pelayanan kesehatan. ${ }^{25}$

Berdasarkan hasil penelitian yang dilakukan oleh Risa Pitriani yang tentang hubungan pendidikan, pengetahuan, dan peran tenaga kesehatan dengan penggunaan kontrasepsi Intra Uterine Device (IUD) di Wilayah Kerja Puskesmas Rawat Inap Muara Fajar Pekanbaru Tahun 2013 mengatakan bahwa adanya hubungan antara pendidikan $(p=0,001)$, pengetahuan $(p=0,036)$, dan peran tenaga kesehatan $(p=0,034)$ dengan penggunaan kontrasepsi IUD. ${ }^{26}$

Berdasarkan hasil penelitian yang dilakukan oleh peneliti bahwa peran bidan merupakan salah satu yang dapat menunjang peningkatan perilaku penggunaan AKDR 
menjadi lebih baik. Jika pengguna AKDR tidak mendapatkan dukungan dari bidan makan perilaku pengguna AKDR menjadi tidak akan baik. Dan hal ini dapat menjadi suatu masalah dan harus dapat segera diperbaiki agar dapat meningkatkan perilaku penggunaan AKDR yang saat ini belum dapat dikatakan dalam berperilaku baik.

\section{Kesimpulan}

Berdasarkan hasil penelitian tentang "Hubungan promosi kesehatan lingkungan dan peran bidan terhadap perilaku penggunaan Alat Kontrasepsi Dalam Rahim (AKDR) di Puskesmas Perumnas I Pontianak Kalimantan Barat Tahun 2017" dapat disimpulkan sebagai berikut : ada hubungan antara promosi kesehatan terhadap perilaku penggunaan AKDR (P-value $=0,004)$, ada hubungan antara lingkungan dengan perilaku penggunaan AKDR $(\mathrm{P}$-value $=0,001)$, ada hubungan antara peran bidan terhadap perilaku penggunaan AKDR (P-Value=0,001).

\section{Saran}

Diharapkan Puskesmas Perumnas I Pontianak lebih dapat meningkatkan promosi kesehatan yang dilakukan khususnya untuk penggunaan Alat Kontrasepsi Dalam Rahim (AKDR) dengan sering melakukan penyuluhan-penyuluhan terkait AKDR ini kepada masyarakat sehingga terjadinya peningkatan penggunaan Alat Kontrasepsi Dalam Rahim (AKDR).

Diharapkan setiap petugas kesehatan khususnya bidan memiliki kemampuan untuk bukan hanya dalam teori saja tetapi dalam kemampuan untuk dapat melakukan pemasangan AKDR bagi pengguna serta mengikuti pelatihan-pelatihan yang diadakan oleh pemerintah setempat agar dapat memperbaharui ilmu yang sedang berkembang khususnya tentang Alat Kontrasepsi Dalam Rahim (AKDR) ini.

Dapat meningkatkan pengetahuan tentang perilaku penggunaan AKDR serta memahami indikator apa saja yang dapat memengaruhi perilaku penggunaan AKDR tersebut dengan membaca buku atau sumber terkait Alat Kontrasepsi Dalam Rahim (AKDR) sehingga peneliti dapat meningkatkan pengetahuan mengenai cara melakukan penelitian dan membuat laporan penelitian agar dapat menghasilkan penelitian yang lebih baik untuk ke depannya dan dapat di jadikan acuan atau referensi bagi peneliti selanjutnya.

Dapat menambah jumlah bahan bacaan di perpustakaan agar dapat lebih memahami tentang perilaku penggunaan Alat Kontrasepsi Dalam rahim (AKDR) dan memberikan materi tidak hanya dalam bentuk teori saja tetapi juga dalam bentuk praktek bagaimana cara melakukan pemasangan Alat Kontrasepsi Dalam Rahim (AKDR) sehingga mahasiswi mengetahuui secara langsung.

\section{Daftar Pustaka}

1. Martini. Pelayanan Keluarga Berencana. Yogyakarta: Rohima Press; 2012.

2. Konferensi Dunia tentang Kependudukan dan Pembangunan (International Conference on Population and Development/ICPD). 1994. Cairo, Mesir. Kompas : 07 Januari 2005.

3. Badan Kependudukan dan Kelurga Berencana Nasional. Pelayanan Keluarga Berencana. diakses pada tanggal 23 febuari 2018. http://id.wikipedia.org/wiki/Penduduk

4. Departemen Kesehatan. Cakupan Peserta Keluarga Berencana. Di akses pada tanggal 17 April 2017 http://eprints.ums.ac.id/37661/4/BAB\%201.pdf

5. Katz K.R.. Jhonson, L.M. Janowitz, B. Carranza, J.M. 2012. Reason for the Low of IUD Use in El Savador, International Family Planning Prespectives, 28(1); 26-31 (Skripsi). El Savador : Oxford Academic; 2012.

6. Elviani Y. Hubungan Paritas dan Sikap Akseptor KB dengan Penggunaan Alat Kontrasepsi Jangka Panjang di Kelurahan Muara Enim Wilayah Kerja Puskesmas Perumnas Kota Lubuklinggau Tahun 2012 (Skripsi). Lubuklinggau : Poltekkes Palembang; 2012.

7. Widiyawati S. Faktor-faktor yang berhubungan dengan pemakaian AKDR (Alat Kontrasepsi Dalam Rahim) di Wilayah Kerja Puskesmas Batuah Kutai Kartanegara Tahun 2012 (Skripsi). Kutai Kartanegara : Universitas Hasanuddin; 2012.

8. Siahaan. Hukum lingkungan dan ekologi pembangunan. Jakarta: Erlangga; 2004.

9. Dyah R.P. Pengaruh Motivasi Kompetensi dan Lingkungan Kerja pada Kinerja Aparatur Penyuluh Keluarga Berencana (Skripsi). Purwokerto: Universitas Jenderal Soedirman; 2011.

10. Friedman. Howards S \& Miriam Schustack. Kepribadian: Teori Klasik dan Riset Modern. Jakarta: Erlangga; 2006.

11. Asri N. Hubungan peran petugas kesehatan dan media informasi dengan perilaku seksual pada ibu pasca nifas di Wilayah Kerja Puskesmas Peukan Bada Kabupaten Aceh Besar Tahun 
2013. (Skripsi). Aceh: STIKES U'Budiyah; 2013.

12. Handayani S. Buku Ajar Pelayanan Keluarga Berencana. Yogyakarta: Pustaka Rihama; 2010.

13. Hidayat A. Metode Penelitian Kebidanan Dan Tehnik Analisis Data. Surabaya: Salemba; 2007

14. Sugiyono. Metode Penelitian Kuantitatif dan Kualitatif dan R\&D. Jakarta: Alfabeta; 2010

15. Sugiyono. Metode Penelitian Kunatitatif Kualitatif dan R\&D. Bandung: Alfabeta; 2008

16. Kusumastuti Dkk. Analisis faktor-faktor yang berhubungan dengan perilaku pelayanan kontrasepsi oleh bidan di Kabupaten Kebumen (Skripsi). Semarang: Universitas Diponerogo; 2015

17. Khoirunissa L. Hubungan dukungan suami dengan pemilihan ontrasepsi IUD pada akseptor kontrasepsi IUD di Puskesmas Tegal Rejo Tahun 2014 (Skripsi). Yogyakarta: STIKES Aisyiyah Yogyakarta; 2014.

18. Suyono H. Bidan Mandiri Sebagai Ujung Tombak Posyandu. Di akses pada tanggal 20 Januari $2018 \mathrm{http}: / / \mathrm{www}$.damandiri.or.id.

19. Pitriani R. Hubungan pendidikan, pengetahuan, dan peran tenaga kesehatan dengan penggunaan kontrasepsi Intra Uterine Device (IUD) di Wilayah Kerja Puskesmas Rawat Inap Muara Fajar Pekanbaru (Skripsi). Pekanbaru: STIKES Hangtuah; 2013. 